\title{
NORTH SUMATRAN MALAY FOLKTALES: ITS STRUCTURE, SOCIAL FUNCTION, AND MEANING
}

\author{
(Cerita Rakyat Melayu Sumatera Utara: \\ Struktur, Fungsi Sosial, dan Maknanya)
}

\author{
T. Thyrhaya Zein \\ tirasinar2005@yahoo.com
}

Faculty of Cultural Sciences, Jl. Universitas 19, Kampus Padang Bulan, Universitas Sumatera Utara, Indonesia.

\begin{abstract}
This study is a descriptive-qualitative analysis that uses the techniques of observation, interviews and written documents. The Systemic Functional Linguistic (SFL) approach based on the principle of semiotics is used in this study. The data analysis consists of folktales found in North Sumatra, that is, "Batu Belah Batu Betangkup", "Putri Kuau" and "Sri Putih Cermin". By using the SFL approach this study describes the structure, social function, and meaning of North Sumatran Malay folktales. From the analysis it is found that the structure, function and meaning of all the three NSM folktales are similar. The material and verbal processes found in the texts of the folktales depict life in the palace and the everyday life of North Sumatran Malay society in the past as well as in the present. North Sumatran Malay texts are the representation of culture and meaning in which the value of of North Sumatran Malay society are inherent.
\end{abstract}

Keywords: folklore, "Batu Belah Batu Betangkup", "Putri Kuau”, "Sri Putih Cermin”, systemic functional linguistics, North Sumatran Malay values 


\begin{abstract}
Abstrak
Kajian ini merupakan penelitian deskriptif-kualitatif yang menggunakan teknik pengamatan, wawancara dan kepustakaan. Pendekatan Linguistik Sistemik Fungsional (LSF) yang berdasarkan prinsip semiotik digunakan dalam kajian ini. Data kajian terdiri daripada cerita rakyat yang terdapat di Sumatera Utara, iaitu "Batu Belah Batu Betangkup", "Putri Kuau" dan "Sri Putih Cermin". Dengan menggunakan LSF kajian akan mengungkapkan struktur, fungsi sosial, dan makna cerita rakyat Melayu Sumatera Utara (MSU). Daripada analisis didapati struktur, ketiga-tiga cerita rakyat MSU ini memiliki struktur, fungsi, dan makna yang mirip. Proses material dan verbalnya yang terdapat dalam teks cerita rakyat menunjukkan cerminan kehidupan istana dan sehari-hari masyarakat Melayu Sumatera Utara baik yang terjadi pada zaman dahulu maupun masa kini. Teks Melayu Sumatera Utara mewakili budaya dan makna sebagai nilai yang dijunjung dan dijiwai oleh masyarakatnya.
\end{abstract}

Keywords: cerita rakyat, "Batu Belah Batu Betangkup", "Putri Kuau”, "Sri Putih Cermin”, linguistik fungsional sistemik, nilai Melayu Sumatera Utara

\title{
INTRODUCTION
}

Oral literature is a tradition that belongs to a particular society. Oral literature is closely linked to that group of people to which it belongs. The content of the stories in oral literature often depict the social cultural situations of a particular society. Typically, oral literature embodies the depiction of a society's social background, culture as well as its belief systems. Oral literature is the product of a culture that has been passed on from one generation to another, such as its traditional expressions, folk poetry, folklore and folk songs. According to Dundes, the definition of oral literature is as follows: “... folklore is a people's symbolic autobiography, ... folklore gives an inside out view of society... folklore was a mirror of culture, a lens for society, a key to behavior, a projection of mind" (Bronner, 2007:viii).

Over many years, oral literature has grown and evolved as part of North Sumatran Malay (NSM) literature. It encompasses prayers, advice, education, mantras, genealogies, normal practices and beliefs. Oral literature in NSM society also functions as a form of entertainment, an educational tool, a means for comparison and advice, and is often the tool for conveying a particular message. The elders passed down their teachings through word of mouth by using the medium of oral literature such as pantun, syair, folk tales, idiomatic expressions (such as pepatah, petitih, bidal, perumpamaan) etc. 
One of NSM's oral literature in the form of prose is folklore. Literary genres such as myth, legend and fantasy are Malay oral literary genres handed down within the Malay society from one generation to another in traditional word form and are closely linked to the tradition of NSM society. It cannot be denied that Malay folklore of North Sumatran society is filled with rich and beautiful language, containing educational, Islamic and highly noble cultural values.

Faced with changes and conflict in cultural values, the elders in the district of Sumut Melayu seldom or no longer narrate their folktales (fantasy or legend) to their children or grandchildren. In the past the elders would often tell their stories, while putting their children to sleep or while chitchatting during leisure time. Since it is now seldom practised, as time goes by they forget the contents of the folktales. This is proven after interviews held with local public figures. Out of the answers to the questions asked of a section of them, it is clear that 50 percent of them showed interest to learn. Whereas on the issue of development, 90 percent admitted they did not participate in its development. Speakers who answered that they use word of mouth as a method of passing on the tradition is 56 percent.

The social phenomenon that is prevalent among the younger generation of North Sumatran society at this moment is due to changes and conflict in cultural values. At this moment the legacy of an untainted Malay culture is not being transmitted as smoothly as in the past. Many tools for transmitting North Sumatran culture used in the past are now disappearing or being forgotten, for example the oral literature tradition in the form of folklore. ${ }^{1}$

The rapid advance of knowledge and technology spreading from the city to the Malay kampongs in North Sumatra has brought a variety of changes in the system of life in this era. Sophisticated knowledge and technology will be able to change the way of thinking and behavior of NSM society which eventually will wipe out the identity and personality of the NSM people.

For the NSM society, knowledge and technology advancement is not forbidden. In fact it is compulsory to learn, absorb and apply these in the best way and as much as possible. However, if knowledge and technology bring more bad than good, or are not compatible with Islamic teaching, culture and values of its customs, then NSM society will lose its own culture. It is hoped that NSM society is able to master sophisticated knowledge and technology but still retain its Malay identity.

With this phenomenon as the starting point, it is therefore necessary to make an analysis of Sumut Malay folklore especially with regard to structure, 
function and meaning of the folktales. Specifically, the problem of this analysis is the structure of the folktales, representing activities in the clauses that are the meaning of the NSM experience. The depiction of the experience can be observed through an experiential function analysis that embodies transitivity analysis. Meanwhile the interpretation of meaning outside the text is done by relating NSM texts with the social context, that is the context of situation and the context of culture. The functions of social, generic and linguistic features contained in NSM folklore, and the interpretation of meaning of NSM texts are observed through the situational context which involves the field, tenor and mode components.

This study is a descriptive-qualitative analysis that uses three techniques: (1) observation (2) interviews (3) written documents. The use of the descriptive method is to systematically describe the facts and data accuracy, nature and relationship of phenomena seen in texts used by NSM speakers academically.

This analysis also presents the qualitative approach, with the alternative of contributing a small component, that is secondary data collection (contributing data). The quantitative data contribution being the result of questionnaires distributed are on a practical level. On the practical level, quantitative data, qualitative technique and method can be used together in a particular study (Sarwono, 2006).

The data sources were obtained from various events or social activities and NSM texts. In this case the source of data, that is oral texts and written texts of NSM folktales are "Batu Belah Batu Betangkup", "Putri Kuau", and "Sri Putih Cermin". Texts as functional language are representations of NSM society. Texts used by NSM society through folktales are a form of communication to convey thoughts, express desire and feelings together with the customs, values and culture of the society. The data sources that support the analysis are the result of interviews with the ethnic people of North Sumatra. The analysis data consists of written and oral texts that represent the experiences of North Sumatran society and texts that contain cultural values depicted through NSM folktales.

\section{LITERATURE REVIEW}

There are many reviews on the Malay language that focus on Malay literature. A number of previous reviews about Malay literature are described as follows. Rosmawati R., Anni Krisna, Ahmad Samin, and Zainal (1990) studied the oral literature of Serdang Malay. The result of the analysis was published by the 
Language Centre, Education and Culture Department in 1990 with the title Struktur Sastera Lisan Melayu Serdang (Structure of Serdang Malay Oral literature). In this study, six structures of folklore prose in Serdang Malay and the oral poetic structure are analyzed. On the whole, this study discusses the development of Serdang Malay oral literature where its relationship with society and the role of oral literature and its development are analyzed. In the analysis of prose structure the theme and plot of the story, protagonists, style, language and advice contained in six Serdang Malay oral prose stories are looked at. Where the poetic structure is concerned, the analysis focuses on rhyme, meaning and theme of the oral poetry of Serdang Malay literature. This study does not use the Systemic Functional Linguistic approach.

In the Analisis Struktur dan Nilai Budaya Cerita Rakyat Sumatera Utara Sastera Melayu (Analysis of Structure and Cultural Values of Folklore in North Sumatra Malay Literature), by Maini Trisna, Suslistiati, and Yeni Mulyani, 30 Malay folktales available in North Sumatra were analyzed in terms of its structure and cultural values. The result of this analysis was published by the Language Centre, Department of Education and Culture in 1997. The main content of the study is the analysis of structure and cultural values of Malay folktales, with regards to theme and advice, approach, personalities, background and cultural values. Similarly this analysis does not use the Systemic Functional Linguistic framework.

The dissertation by Ab. Razak (1998) entitled "Warkah-warkah Melayu Lama sebagai Genre" (Old Malay letters as a Genre) is an analysis of old Malay letters, either social letters or agreements which make up one specific genre based on format, technique and content of the letters. This study also focuses on the form of strategy, communication and etiquette used by the sender. Ab Razak's study contributes to this analysis in matters of generic structure of old Malay letters that have its own special features.

\section{FUNCTIONAL LINGUISTIC APPROACH}

In order to describe the structure, social function and meaning of NSM folklore, all the folktales are analyzed based on the Systemic Functional Linguistic (SFL) approach, which in language studies is an approach based on the principle of semiotics. Language is based on signs and therefore is also described as social semiotics (Halliday, 1978). The linguistic theory with a semiotic viewpoint or approach towards language is the SFL theory developed by Halliday (1978, 2004), Martin (1992), Eggins (2004), Halliday 
and Matthiessen (2001). In other words, systemic functional grammar is grammar based on semiotic principle or semiotic principle is the main foundation of systemic functional grammar.

From the SFL perspective, language studies are tied to social contexts. Language is a social phenomenon that exists in social semiotics. The semiotics of language usage is made up of denotative semiotics and connotative semiotics. Denotative semiotics is formed in the link between language aspects based on semantics, grammar (lexicogrammar) and phonology or graphology. In language usage, connotative semiotics is found in the link between language and social context based on ideology, cultural context and situational context. The relationship between text and context determine each other. When simplified, the close link between language and social context can be explained as follows. Language as text with its variety of aspects is a form of expression or realization arising from a situation, and situation is a form of expression or realization arising from genre or culture.

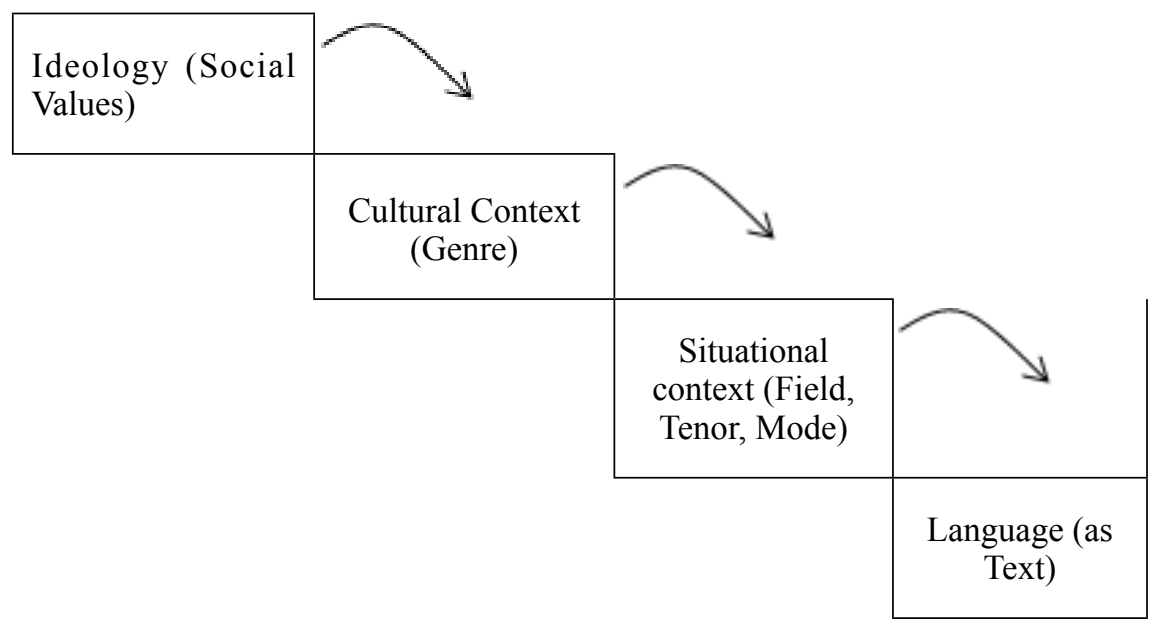

Figure 1 Relationship between Language and Context (adapted from Martin 1992:493, 495).

SFL theory is a suitable tool for analyzing North Sumatran folktales. The first reason is, language is an expression of social behaviour in context: the meaning from every text is dependent on the context. Context refers to the relationship between text and situational and cultural context because 
of the dependence of linguistic meaning on cultural context. In other words, language use is contextual, specifically, language is context-dependent.

The second reason is due to their viewpoint that language exists to serve human needs. Therefore this study focuses on the importance of speakers understanding language usage because language has the function of catering to human needs in its significance in context.

At the language level, text is analyzed based on the transitivity system that involves three components, that is process, participant and circumstance. Process refers to activity that occurs in a clause which is the meaning of the experience that determines the type of participant that follows it. Process is used as the basis for labelling participants in clauses. A process that is taking place is divided into various processes, that is; 1) material process 2) mental process; and 3) relational process, and three additional processes that include 1) behavioural process; 2) verbal process; 3 ) existential process. Participants are people or things that are involved in a process. The role of participant is tied to process and circumstance which is the limit, nature or location in which the process involving the participant occurs. Participants include actors, goals, sensers, phenomena, signs, values, carriers, attributes, owners, possession, behaver, words and objects. Apart from these, a participant that unites with the process is called range and a participant outside the process is normally called beneficiary which is labelled based on the type of process. The circumstance component is equivalent to an explanation and occurs in all types of processes. Circumstance occurs on a range that can be in the form of distance or time, location that can either be place or time, manner, cause, scope, participant, role, problem and viewpoint.

At the level of context of situation, three components are applicable, that is field, which is what is being discussed; tenor, which is the one discussing a particular topic; and mode, which is the way the discussion is held. Field is related to the organization of an object or social activity that interacts and has two dimensions, i.e. what is being discussed and for what it is discussed. Field also covers several components like arena or activity, nature of the tenor and the semantic domain. Mode is related to the role and function of language referring to how the discussion is held and mode also covers planning, distance components as well as medium and channel. Tenor focuses on who discusses, and includes the components of formality, status, affection and contact. Through situational analysis the meaning contained in North Sumatran folktales can be realized.

With regard to the context of culture, this study refers to the genre concept taken from the operational definition offered by Martin (Martin, 
1985b; Martin,1992). Genre is defined as a staged and goal-oriented social process (Martin, 1985b; Martin,1992). The social function referred to in the definition of genre is the person who uses genre to communicate with others; goal-oriented means the person who uses the genre is able to achieve the goal of communication; and staged denotes that in achieving the communication goal there are certain steps or stages to go through.

Text and context are interdependent. Context refers to the relationship between text and contexts of situation and culture. Therefore, with regard to this study NSM texts are the representation of culture and meaning in which the values of North Sumatran society are inherent.

\section{ANALYSIS OF STRUCTURE, FUNCTION AND MEANING OF NSM FOLKLORE}

As presented earlier in this study that text analysis is realized through its structure, function and meaning, the following is an analysis of the structure, function and meaning of NSM folklore based on the Systemic Functional Linguistics (SFL) approach. In the analysis of the structure of NSM folklore, all the clauses found in the NSM Malay folktales are analyzed based on the transitivity system and labelled according to the components of process, participant and circumstance. In the analysis of function and meaning, NSM folktales are analyzed based on social context, that is the analysis of meaning is realized through field, mode and tenor and the analysis of function realized through generic structure or a staged and goal-oriented social activity. Text analysis is supported by context analysis and vice versa. Therefore text really functions in accordance with context. The analysis of structure, function and meaning of three NSM folktales are as follows:

\section{Structure of NSM folktales}

a. Structure of folktale "Batu Belah Batu Betangkup"

At the level of language, text is analyzed based on the transitivity system that is made up of three components, that is process, participant and circumstance

\section{Process}

The total number of clauses in the folktale "Batu Belah Batu Betangkup" ("BBBB") is 40. Material 50 percent, mental 20.83 percent, verbal 10.41 percent, relational 8.33 percent, behavioral 6.25 percent and existential 4.16 
percent. There are six types of processes represented in the "BBBB" story that is, material, mental, relational, behavioral, verbal and existential processes. The processes that dominate in this folktale are the material process, totaling 24 processes (50 percent) and the mental process totaling 10 processes or 20.83 percent. A number of verbs or verbal groups that have been labeled as material process are as follows: live, search, work, meet, grow, born, given, help, die, work, help, fall, help, go down, go, run, follow, eaten, split, enter, swallowed. Those that have been labeled as mental processes are the following verbs : think, decide, know, shame, predicted, conscious, heard. Meanwhile the relational processes found in this folktale are verbs such as have, by the name of, is, are, become, named. This can be seen from a number of material and mental $p$ rocesses found in the "BBBB" folktale.

Clause [2]

Mereka tinggal di sebuah dusun yang terpencil

They live on a remote farm.

\begin{tabular}{|l|l|l|}
\hline $\begin{array}{l}\text { Mereka } \\
\text { They }\end{array}$ & $\begin{array}{l}\text { tinggal } \\
\text { live }\end{array}$ & $\begin{array}{l}\text { di sebuah dusun yang terpencil } \\
\text { on a remote farm }\end{array}$ \\
\hline Actor & Process:Material & Circ.:Location:Place \\
\hline
\end{tabular}

Clause [6]

bekerja mengayam tikar.

works by weaving mats.

\begin{tabular}{|l|l|l|}
\hline $\begin{array}{l}\text { bekerje } \\
\text { works }\end{array}$ & $\begin{array}{l}\text { menganyam } \\
\text { weaving }\end{array}$ & $\begin{array}{l}\text { tikar } \\
\text { Mat }\end{array}$ \\
\hline Process:Material & Process:Material & Goal \\
\hline
\end{tabular}

Clause[12]

Dan aku tahu ape yang Mak Siti disusahkan.

And I know what Mak Siti is worried about.

\begin{tabular}{|l|l|l|l|}
\hline $\begin{array}{l}\text { Dan } \\
\text { And }\end{array}$ & $\begin{array}{l}\text { aku } \\
\mathrm{I}\end{array}$ & $\begin{array}{l}\text { tahu } \\
\text { know }\end{array}$ & $\begin{array}{l}\text { ape yang Mak Siti susahkan } \\
\text { what Mak Siti is worried about }\end{array}$ \\
\hline & Senser & Process:Mental & Phenomenon \\
\hline
\end{tabular}

Clause [24]

Kamala tak suke membantu ibunya.

Kamala does not like to help her mother. 
MALAY LITERATURE VOLUME 28 NUMBER 22015

\begin{tabular}{|l|l|l|l|}
\hline $\begin{array}{l}\text { Kamala } \\
\text { Kamala }\end{array}$ & $\begin{array}{l}\text { tak suke } \\
\text { does not like }\end{array}$ & $\begin{array}{l}\text { membantu } \\
\text { to help }\end{array}$ & $\begin{array}{l}\text { ibunya } \\
\text { her mother }\end{array}$ \\
\hline Senser & Process:Mental & Process: Material & Goal \\
\hline
\end{tabular}

\section{Participant}

In the folktale BBBB, there are 16 participant, actors equivalent to 26.67 percent, senser participants total 6 or 10 percent, symbol and carrier participants total 4 or 6.67 percent. There are 8 goal participants, equivalent to 13.33 percent and range participants totaling 7 or 11.67 percent, and phenomenon participants totalling 5 or 8.33 percent.

The majority of participants found in the "BBBB" folktale are human participants who appear in nominal groups such as husband and wife, they, her husband, his wife, pak Abu, mak Siti, descendants, our child, granny, wanderer, I, you, that granny, a princess, Kamale, his princess, her parents, mak Siti's husband, her mother, I, she, her child, mother, and herself. The participants found in BBBB folktale are fictional because they are figures of imagination created by the narrator to appear in the folktale. Although the said participants mentioned are not real, they are representations of NSM society.

However, not many non-human participants are found, only nominal groups such as his work, mat, body, split rock and stone. This shows that objects such as split rock are not factual objects. Whereas things like mat is a factual object and closely linked to the lives of MSN society. Mats are the result of diligent handiwork by the weavers of mats along the Malay beach areas. The reality is, much of NSM women's earnings in the districts of Serdang and Langkat are from weaving mats. Mats are used in the daily lives of NSM folks either at home or during certain activities or events.

\section{Circumstance}

There are five types of circumstances totaling 14 in the "BBBB" folktale. The five are: circumstance: range: time; circumstance: location: place; circumstance: location: time; circumstance: manner; and circumstance: cause. The biggest number out of the five is that of location: time and circumstance: manner, each totalling 5, equivalent to 35.71 percent. The second place goes to circumstance: range: time which is 14.29 percent, circumstance: location: place at 7.14 percent, circumstance:location: time at 28.57 percent, circumstance: manner at 28.57 percent, circumstance: cause 7.14 percent. 


\section{b. Structure of foktale "Putri Kuau"}

\section{Process}

The following is a representation of the processes in a mythical folktale entitled "Putri Kuau" ("PK"). The total number of clauses in the folktale "PK" is 182 clauses. In "PK" six types of processes are found, that is material, mental, relational, behavioural, verbal and existential. The processes that dominate the text of this NSM folktale are the material process which is 55.49 percent, followed by verbal process 15.93 percent and mental process 14.28 percent. Whereas the other processes are relational 7.69 percent, existential 5.49 percent and behavioral 1.09 percent. The material process (verb) found in "PK" are hunting, trapping, standing, perch, walk across, peck, caught, carried, put in, tied up, cast net, approached, eat, pass, found, gathered, cook, taken, hidden, look for, step, tied up, taken, hidden, looke for, keep, got married, born, separated, go through, cradle, fly, fall, crushed. The following are several clauses from a number of processes found in the folktale "PK".

Clause [2]

Jadi pade suatu hari raje berburu ke hutan.

So one day the king went hunting in the forest

\begin{tabular}{|l|l|l|l|l|}
\hline $\begin{array}{l}\text { Jadi } \\
\text { So }\end{array}$ & $\begin{array}{l}\text { pade suatu hari } \\
\text { one day }\end{array}$ & $\begin{array}{l}\text { raje } \\
\text { king }\end{array}$ & $\begin{array}{l}\text { berburu } \\
\text { Went hunting }\end{array}$ & $\begin{array}{l}\text { ke hutan. } \\
\text { In the forest }\end{array}$ \\
\hline & $\begin{array}{l}\text { Circ.Location: } \\
\text { time }\end{array}$ & Actor & Process:Material & $\begin{array}{l}\text { Circ: } \\
\text { location:place }\end{array}$ \\
\hline
\end{tabular}

Clause [55]

Pade suatu malam, seperti biasenya, raje pun lalu ke sungei untuk menjala ikan. One night, as usual, the king went to the river to catch fish

\begin{tabular}{|l|l|l|l|l|l|l|}
\hline $\begin{array}{l}\text { Pade suatu } \\
\text { malam, } \\
\text { One night }\end{array}$ & $\begin{array}{l}\text { seperti } \\
\text { biasenye, } \\
\text { as usual, }\end{array}$ & $\begin{array}{l}\text { raje } \\
\text { pun } \\
\text { king }\end{array}$ & $\begin{array}{l}\text { lalu } \\
\text { went }\end{array}$ & $\begin{array}{l}\text { ke sungei } \\
\text { to the } \\
\text { river }\end{array}$ & $\begin{array}{l}\text { untuk } \\
\text { menjale } \\
\text { to catch }\end{array}$ & $\begin{array}{l}\text { ikan } \\
\text { hasil } \\
\text { jaliannya } \\
\text { fish }\end{array}$ \\
\hline $\begin{array}{l}\text { Circ: } \\
\text { Location: } \\
\text { Time }\end{array}$ & & Actor & $\begin{array}{l}\text { Process: } \\
\text { Material }\end{array}$ & $\begin{array}{l}\text { Circ: } \\
\text { Location: } \\
\text { Place }\end{array}$ & $\begin{array}{l}\text { Process: } \\
\text { Material }\end{array}$ & Goal \\
\hline
\end{tabular}


Clause [58]

sekali-kali keleh ikan hasil jaleannye.

Once in a while he looked at the fish he had caught

\begin{tabular}{|l|l|l|l|}
\hline $\begin{array}{l}\text { sekali-kali } \\
\text { Once in a while }\end{array}$ & $\begin{array}{l}\text { le } \\
\mathrm{He}\end{array}$ & $\begin{array}{l}\text { keleh } \\
\text { Looked at }\end{array}$ & $\begin{array}{l}\text { hasil jaleannye. } \\
\text { The fish he had } \\
\text { caught }\end{array}$ \\
\hline & Senser & Process: Mental & Phenomenon \\
\hline
\end{tabular}

Clause [131]

radukan (nyanyikan) anak kita ni, kate raje.

Sing for our son, said the king.

\begin{tabular}{|l|l|l|}
\hline $\begin{array}{l}\text { radukan (nyanyikan) } \\
\text { sing }\end{array}$ & $\begin{array}{l}\text { anak kita } \text { ni } \\
\text { For our son }\end{array}$ & $\begin{array}{l}\text { kate raje } \\
\text { Said the king }\end{array}$ \\
\hline Process: Verbal & Phenomenon & Process:Verbal \\
\hline
\end{tabular}

\section{Participant}

In the folktale "PK", 70 actor participants are found, equivalent to 33.98 percent, sensers total 24 which is equivalent to 11.65 percent and carriers total 22, equivalent to 10.68 percent. Whereas goal participants total 49 which is equivalent to 23.79 percent and phenomenon participants total 15 , equivalent to 7.28 percent. The participants found in the folktale "PK" are both human and non-human participants

The human participants represented in this story are the participants you, I, they, he/she, the old man, his child, while those represented through imaginative figures are the participants king, his highness, a princess and the princess. The non-human participants are living things in the form of animals such as kekuau bird and fish and the living thing participants in the form of plants are tree, tree trunk, branches and river and the environmental participant is rain.

The non-human participants in the form of objects are the participants cage and palace. Although the participants king, his highness, a princess and the princess are not real, the princess and king characters as well the kingdom's background such as this are common in Malay folktales generally. ${ }^{2}$ The participant fish found in "PK" is a living thing participant which is closely connected to the North Sumatran fisherman's way of life. It is mentioned in the story that the king always goes fishing or casting his net. The activity of the king doing so is a depiction of the NSM way of life, 
where a big percentage of the people are fishermen and a depiction of the Sumatran shores' way of life.

\section{Circumstance}

After explaining the component participants in the three folktales, we move on to the circumstance component. In the "PK" folktale, there are five types of circumstances with totalling 14 altogether. The five types are circumstance: range: time, circumstance: location: place, circumstance: location: time, circumstance: manner, and circumstance: cause. The biggest number from the five types of circumstances is of circumstance: location: time and circumstance: location: manner, both amounting to 5 each and equivalent to 35.71 percent. The second stage is dominated by circumstance: range: time which is 14.29 percent, circumstance: location: place 7.14 percent, circumstance: location: time 28.57 percent, circumstance: manner 28.57 percent and circumstance: cause 7.14 percent.

\section{c. Structure of Folktale "Sri Putih Cermin"}

\section{Process}

Next is the transitivity representation of the the legendary folktale entitled "Sri Putih Cermin" ("SPC"). All the clauses are analyzed based on their process, participant and circumstance components. The total number of clauses from the "SPC" folktale is 64 and after an analysis of its processes, it is found that there are six types, that is material, mental, relational, behavioral, verbal, and existential. The process that dominates in this folktale is the material process totaling $34,(53.12$ percent), relational process takes second place at 7 processes or 10.93 percent. The following three processes that is behavioral, verbal and existential have less than 5 percent that is 3.12 percent, 4.68 percent and 3.12 percent. The material process (verb) that dominates the "SPC" folktale can be seen from the following verbs: grab, rescue, defeated, rescue, threaten, attack, bring, look for, conquer, meet, marry, sucked, kill, got (married), enthroned, and submerged. The following are several clauses representing the material, relational and mental processes.

Clause [8]

Gadis itu memutuskan untok pergi mencari kekasehnye dengan membawe tombak Serampang Sakti milik kerajaan. 
MALAY LITERATURE VOLUME 28 NUMBER 22015

The girl decided to go and look for her lover bringing with her the spear Serampang Sakti belonging to the kingdom

\begin{tabular}{|l|l|l|l|l|l|}
\hline $\begin{array}{l}\text { Gadis } \\
\text { itu } \\
\begin{array}{l}\text { The } \\
\text { girl }\end{array}\end{array}$ & $\begin{array}{l}\text { memutus- } \\
\text { decided }\end{array}$ & $\begin{array}{l}\text { untok } \\
\text { pergi } \\
\text { to go }\end{array}$ & $\begin{array}{l}\text { mencari } \\
\text { look for }\end{array}$ & $\begin{array}{l}\text { kekaseh- } \\
\text { nye } \\
\text { Her } \\
\text { lover }\end{array}$ & $\begin{array}{l}\text { dengan membawe } \\
\text { tombak Serampang } \\
\text { Sakti milik kerajaan. } \\
\text { Bringing with her } \\
\text { the spear Serampang } \\
\text { Sakti belonging to the } \\
\text { kingdom }\end{array}$ \\
\hline Senser & $\begin{array}{l}\text { Process: } \\
\text { Mental }\end{array}$ & $\begin{array}{l}\text { Process: } \\
\text { Material }\end{array}$ & $\begin{array}{l}\text { Process: } \\
\text { Material }\end{array}$ & Goal & Circ: Participant \\
& Mall & & \\
\hline
\end{tabular}

Clause [2]

Raja itu mempunyai seorang putri yang cantik jelita bernama Sri Putih Cermin atau Tuanku Kemale Putri.

The king had a beautiful daughter by the name of Sri Putih Cermin or Tuanku Kemale Putri.

\begin{tabular}{|l|l|l|}
\hline $\begin{array}{l}\text { Raja itu } \\
\text { The King }\end{array}$ & $\begin{array}{l}\text { mempunyai } \\
\text { had }\end{array}$ & $\begin{array}{l}\text { seorang putri yang cantik jelita bernama Sri Putih } \\
\text { Cermin atau Tuanku Kemale Putri. } \\
\text { a beautiful daughter by the name of Sri Putih Cermin } \\
\text { or Tuanku Kemale Putri'. }\end{array}$ \\
\hline Owner & $\begin{array}{l}\text { Process: } \\
\text { Relational: } \\
\text { possession }\end{array}$ & Possess \\
\hline
\end{tabular}

Clause: [14]

kerana menurut adat resam masa tu kepergian cara demikian amatlah memalukan keluarga kerajaan,

because according to the traditional customs of that time such a departure was very embarrassing for the family and the kingdom'

\begin{tabular}{|l|l|l|l|l|}
\hline $\begin{array}{l}\text { kerana menurut adat } \\
\text { resam masa tu } \\
\text { because according } \\
\text { to the traditional } \\
\text { customs of that time }\end{array}$ & $\begin{array}{l}\text { kepergian } \\
\text { cara } \\
\text { demikian } \\
\text { such a } \\
\text { departure }\end{array}$ & $\begin{array}{l}\text { amat- } \\
\text { lah } \\
\text { very }\end{array}$ & $\begin{array}{l}\text { memalukan } \\
\text { embarrassing }\end{array}$ & $\begin{array}{l}\text { keluarga } \\
\text { kerajaan } \\
\text { to the family } \\
\text { and the } \\
\text { kingdom }\end{array}$ \\
\hline Circ: Viewpoint & Senser & & $\begin{array}{l}\text { Process: } \\
\text { Mental }\end{array}$ & Phenomenon \\
\hline
\end{tabular}


After representing the findings of the processes in the folktale "SPC", next, the participants in the folktale are represented.

\section{Participant}

In the folktale "SPC", there are participants that include actors, incumbents, sensers and others such as symbols, owners, carriers, objects and behavers, Whereas the participants at whom the process is directed are participants such as goals, attributes, values, possesion, phenomenon, verbiage, and beneficiaries. The biggest number of participants in this story is actor participants totaling 52 which is equivalent to 42.98 percent, incumbents totalling 10 which is equivalent to 8.26 per cent and sensers totaling 5 or 41.3 per cent. The goal participants total 23 which is equivalent to 19.01 percent and attribute participants total 16 or 13.22 percent and phenomenon participants total 4 or 3.31 percent.

The human participants represented in this folktale are you, I, they, herself, he, youth, her lover whereas those represented through imaginative figures are the queen, the king, his highness, Marajaye, raje Indra Bongsu, a princess, princess, a mythical princess and Sri Putih Cermin. The non human participants that are living things in the form of animals is lidah tanah, and living things in the form of plants is wood, and the environmental participants are stormy winds, flood. Whereas the non-human participants in the form of objects are the spear Serampang Sakti, kingdom and palace.

\section{Circumstance}

In the SPC folktale there are five types of circumstances in which a total of 15 are made up of; circumstance: location: place; circumstance: location: time; circumstance: method; circumstance: problem; circumstance: participant; and circumstance: range: time. Circumstance: location: place has the biggest total among the five types of circumstances, that is 8 which is equivalent to 53.33 percent. The second biggest number is that of circumstance: participant at 20.00 percent and finally circumstance: manner and circumstance: problem which take up 6.66 percent each.

Based on the distribution figures of process, participant and circumstance in all three NSM folktales (see Figure 2), the texts are found to be dominated by; 1) material process followed by mental process and verbal process; 2) participant actor, senser, participant carrier, and participant which is the target, that is, goal, phenomenon and attribute and; 3) circumstance: location: time followed by circumstance: location: place and location: participant. 


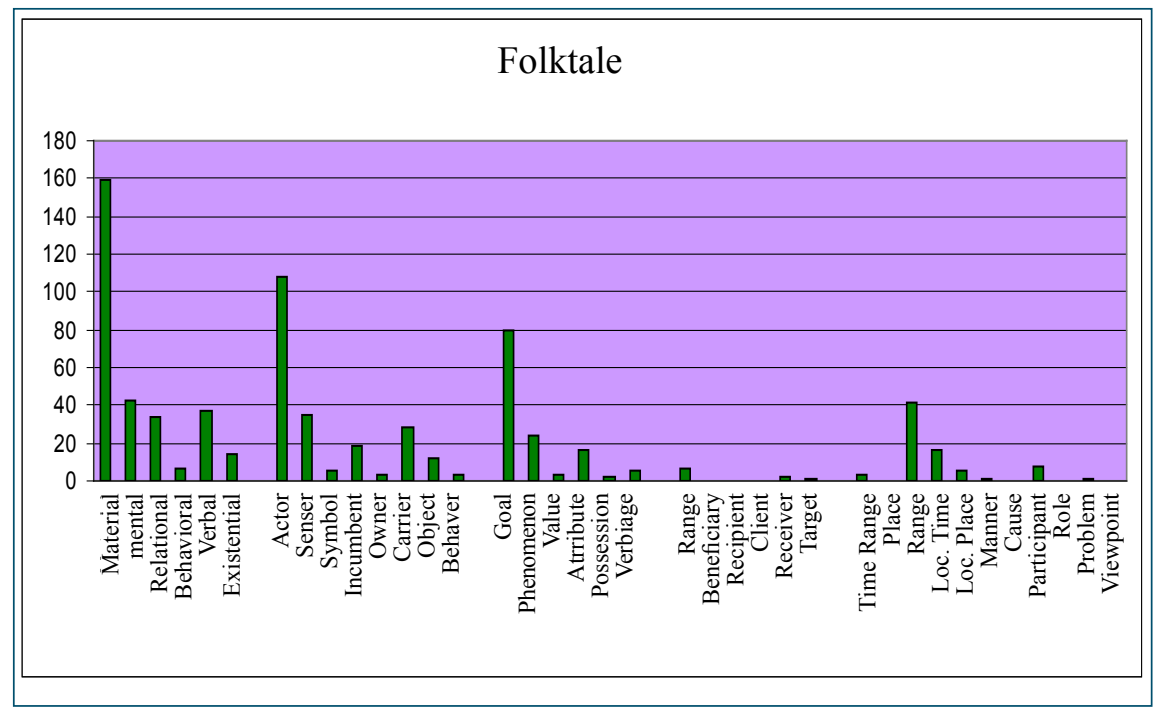

Figure 2 Frequency Distribution of Process, Participant, Circumstance in NSM Folktales

\section{Analysis of Meaning of NSM Folktales}

By linking text with context, this study links text with situational context. At the level of situational context, the NSM texts are built up from field, tenor and mode. Combining field, tenor and mode will help in understanding NSM texts.

In this study, the NSM text field is related to the core of the issue being discussed through the use of language in text. Text contains the experiential meaning that represents language relatedness with reality and shows the stage of NSM text with the activity being carried out. The following is an analysis of the meaning of three NSM folktales based on the situational context.

\section{a. The Meaning of the Folktale "BBBB"}

In order to analyze the meaning of NSM folktales, the analysis is based on context of situation that focuses on three components, that is field, tenor and mode. The field in "BBBB" is about a mother who yearned for a child but when she finally had one, the child never wanted to help her mother until the mother became extremely sad and pleaded for the cave to swallow her. The 
first tenor is Muhammad Nurdin, a sixty-year old man, a prominent Tanjung Pura Langkat society figure. The semantic domain that describes the content or core is the Langkat Malay folklore. The tenor is very eloquent in narrating the legend. The tenor in singing the legend occupies two positions, that is tenor 1 as narrator and tenor 2 as listener. In this situation, the narration activity is formal (-) and takes place in a relative's backyard. The content or core being discussed is the Langkat Malay folklore. There are not many young people who know the oral literature in this form of prose. With this limitation therefore the activity $(+)$ is the specialization of the elderly in Sumatran society. The status of tenor 1 and tenor 2 are in a different or unbalanced position.

Continuum 1: Social Status (speech) Tenor 1 towards Tenor 2

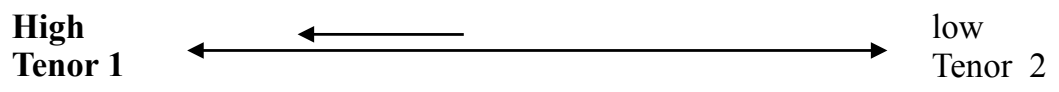

Affection shows the existence of emotion between tenor 1 and tenor 2. The link between the tenors is in positive affection meaning tenor 1 and tenor 2 respect and like each other. By its nature, affection determines the use of language as a continuum with interpersonal $(+)$ on one side which means that two persons are involved in an interaction of amicableness and a big part of it involves the element of emotion.

The planning of the activity of storytelling is on a planned continuum $(+)$, that is the activity of singing the syair takes place in a scheduled manner at the house of tenor 1 in Tanjung Pura, Langkat. The distance between the tenors is on a $(+)$ continuum of distance in time/place on one side because the time and place factors really determine it. The activity or scenario of storytelling requires a direct response or in other words perception from the other tenor. The event of using text at the moment the activity takes place is referred to as action. Therefore, the level of relatedness of language is the semantic distance continuum $(+)$ meaning there is distance between the text and the activity of narrating the folktale "BBBB".

\section{b. The Meaning of the Folktale "PK"}

The following is an analysis of the meaning of the folktale "PK" based on the situational context. The field of "PK" is about a prince who married a 
mythical princess but she turned into a bird and flew back to the heavens after the prince asked her to sing the syair "Kuau". In the end, the prince regretted the incident. The content or core conveyed by the story are the cultural values like: 1) heeding advice; 2 ) strong determination; 3 ) diligence.

Regarding the first cultural value: heeding advice is clearly shown when the prince did not listen to his wife, the Kuau princess in that he should not ask her to sing the syair "Kuau". Since the prince did not heed his wife's advice, the Kuau princess finally turned back into a bird. The second value, strong determination is shown in the attitude of the prince when he wanted to capture the Kuau bird. He thought of ways to catch the bird. And the third value is diligence. This value can be seen from the attitude of the Kuau princess who worked hard to fulfil her responsibilities in the palace, especially by cooking for the prince.

The activity of storytelling is an instituted $(+)$ activity. The character of tenor 1 is Yuhani binti Imam Amir, an old lady 59 years of age, working as a farmer. Tenor 2 is an observer, a 45 -year old woman, married with a strata 2 education. There is planning for this activity of narrating the legend Putri Kuau, scheduled at the house of tenor 1 at Desa Mesjid, Dusun III, Kelurahan Tani Beringin, Kecamatan Batang Kuis, Kecamatan Delisedang. Therefore, the planning of this activity is said to be on a planned continuum $(+)$. The distance between tenors is on the distance in time/ place continuum on one side because the factors of time and place really determine it. The activity or scenario of storytelling requires direct response or in other words perception from the other tenor. The event of using text at the moment the activity is carried out is referred to as action. Therefore, the level of language relatedness is the $(+)$ semantic distance continuum, meaning there is distance between the text and the activity of narrating the legend "PK". The channel or medium realized during the storytelling is the oral medium.

\section{c. The Meaning of the Folktale, "SPC"}

Next is an analysis of the meaning of the NSM folktale entitled "Sri Putih Cermin" based on its situational context. The content or core conveyed in "SPC" are the cultural values espousing: 1) obedience and respect for elders; 2) loyalty and responsibility; 3) wisdom; 4) faithfulness and love for each other.

Cultural value (1) obedience and respect for elders is a common custom in Malay society in that girls at that time should stay at home. However in this story, a conflict emerges through an imaginative figure, a girl by the 
name of Kemala Putri (Sri Putih Cermin) who throws convention or custom to the winds by leaving the palace carrying a spear belonging to the kingdom to follow a young man, her lover. From value (2) loyalty and responsibility, what is hinted at is the hastiness of the imaginative figure Marajaye, Kemala Putri's lover, in choosing his future wife. The hasty and incautious decision in choosing a wife would result in catastrophe, for oneself and for others. The cultural value (3) wisdom, is depicted through the imaginative figure Marajaye, regarded as a good man and not revengeful in nature. Marajaye's character is portrayed as heroic, quick-thinking, brave and wise while his friends attempted to destroy him. The last cultural value (4) loyalty and love for each other is represented through Sri Putih Cermin's faithfulness to her lover, Marajaye, and how she came to his aid without hesitation.

Tenor 1 is Datuk Sayuti, a society figure, aged 60, at Desa Besar II Terjun, Kecamatan Pantai Cermin, Kabupaten Serdangbedagai. Tenor 2 are the village youths who listen to the story by this society figure. It can be stated that the planning of the storytelling activity is on a planned $(+)$ continuum. The narrating also took place in a scheduled manner at the house of tenor II. The distance between tenors is on the distance in time/place continuum $(+)$ on one side because the factors of time and place really determine it.

At the moment the activity of text usage takes place is called action. Therefore, the level of language relatedness is the $(+)$ semantic distance continuum meaning there is distance between text and activity of narrating the legend Sri Putih Cermin. The channel or medium realized in the telling of the story is the oral medium. At one corner of the continuum, there is an oral text realized by a voice with intonation.

From the analysis of the three folktales it is found that NSM legacy of folklore embodies the dimension of man's relationship with each other, the solidarity between human beings. This dimension contains cultural values and lessons such as: obedience and respect for elders, faithfulness and love for each other, responsibility, wisdom. In addition, there is also moral advice in the folklore so that human beings possess life ethics which are good and true.

\section{Analysis of Social Function of NSM Folklore}

In analyzing social function, this study links text with cultural context (genre). Genre is defined as a social process that is staged and goal-oriented (Martin, 1985b; Martin, 1992). The word "social" that is referred to is the person who uses genre to communicate with others; the term "goal-oriented" means the person who uses genre is able to achieve the goal of communication and 
"staged" means that in achieving the purpose of communication several steps or stages are needed through periodization. The step or stage that needs to be taken in the technical interaction is called generic structure or schematic structure.

On a larger scale, the purpose and function of social text is achieved by taking advantage of lingual forms found in the text. Specifically, the lingual forms are linguistic features or traits which are internally inherent in it.

The cultural values found in the cultural context (genre) are realized by the social process. The social process in the society covers the verbal social process and non-verbal social process. The verbal social process is simply called genre (Santosa, 2003:23). Genre that is found in the cultural context contains cultural values and norms of a society and to achieve the communication several steps or stages have to be taken. The following is an analysis of NSM folktale texts based on cultural context (genre) that covers the social function, generic structure and linguistic features.

\section{The Purpose and Social Function of Folklore}

The folktale "BBBB" has a social purpose and function, that is to tell the story of an ungrateful child with the purpose of giving a moral lesson to listeners as well as to entertain listeners or readers. The social purpose and function of the folktale "PK" is to tell the story of the Princess Kuau who heeded the advice given to her, has a strong determination and is diligent. This legend is meant to provide an example to listeners or readers about a person's obedient nature. In addition the folktale "PK" also aims to entertain listeners or readers. The purpose and function of the folktale "SPC" is to tell the story of the origin of Pantai Cermin, delivered either orally or in written form with the purpose of giving a moral lesson to listeners and also to entertain listeners or readers.

\section{Generic Structure of Folklore}

The generic structure of "BBBB" narration consists of smaller elements at every stage. The levels of complication and resolution are divided into smaller elements, such as a complication made up of two smaller elements, that is major complication and minor complication, whereas resolution consists of a smaller element, that is major resolution. These elements clarify the generic structure in greater detail.

The generic structure of "BBBB" narration is detailed as follows: [Abstract ${ }^{\wedge}$ [Orientation] ${ }^{\wedge}$ [Complication [Minor Complication, Major 
Complication] $]^{\wedge}[$ Resolution [Major Resolution]]. There is no element of Code in this legend.

As the generic structure of "BBBB" and "PK" narration have smaller elements at every stage, so does the generic structure of SPC narration which can be detailed as follows: $[\text { Abstract }]^{\wedge}[\text { Orientation }]^{\wedge}[$ Complication [Minor Complication, Major Complication] ${ }^{\wedge}$ [Resolution [Major Resolution]] $\wedge$ [Code].

The abstract of the narration begins with the depiction of a king who has a beautiful daughter who is in love with, and is loved by a brave young man. Complication arises when the author introduces a conflict through the role of Kemala Putri (Sri Putih Cermin) who throws convention and custom to the winds. The Princess leaves the palace bringing with her a spear belonging to the kingdom as she goes in search of her lover. There is resolution when Sri Putih Cermin returns to the kingdom and succeeds in killing si Lidah Tanah with the spear Serampang Sakti and then marries Marajaye, her lover. This story has repeats of complication and resolution elements until finally it is marked with a code or the ending element of "SPC" narration.

In these folktales, the narrator attempts to create an imaginative world to stir the readers' imagination towards the story. Although the reader is brought into a world of imagination, the narration also carries educational values and provide information as well as cause the reader to reflect on his own experiences.

\section{Lingusitic Features in Folktales}

The folktale "BBBB" has linguistic realizations which become the features of this folktale. The special characteristics of the linguistic features found in the genre NSM Folktale narratives are: 1) the text is dominated by the material process; 2 ) there are specific participants in the form of imaginative figures labeled as actor participant and goal participant; and 3) use of circumstance: location: time. Although this narrative text is non-factual or imaginative, the text is a representation of life in the past that linger in the minds of the NSM society.

The linguistic features found in the genre NSM folktale narrative entitled "PK" are: 1) the text is dominated by the material process; 2) there are specific participants in the form of imaginative figures labeled as actor participant and goal participant; 3 ) use of circumstance: location: time. Although this narrative text is non-factual or imaginative, the text is a representation of life in the past that linger in the minds of the North Sumatran society. 
The linguistic features found in the NSM folktale entitled "Sri Putih Cermin" are: 1) the text is dominated by the material (verbal) process; 2) the human participants represented in "SPC" include the participants you, I, they, himself, he, young man, lover whereas those represented by imaginative figures are participants queen, king, his highness, Marajaye, raja Indera Bongsu, a princess, the princess, a mythical princess and Sri Putih Cermin. The non-human participants are participants in the form of animals such as lidah tanah and living things in the form of plants is wood and environmental participants such as stormy winds, flood. Meanwhile, the non-human participants in the form of objects are the participants the spear Serampang Sakti, kingdom, and palace; 3) there are five types of circumstances in "SPC" that is: circumstance: location: place; circumstance: location: time; circumstance: manner; circumstance: problem; circumstance: participant; and circumstance: range: time. The biggest number from the five types of circumstances is from circumstance: location: place.

\section{CONCLUSION}

In relation to the analysis on structure, function and meaning of NSM folktales, it can be concluded that the three folktales "BBBB", "PK" and "SPC" have similar structure, function and meaning.

It is found that the three folktales, "BBBB", "PK" and "SPC" have a structure dominated by the material process, totaling 34 processes $(53.12$ percent) in all. Several examples of material and verbal processes, such as weaving mats, casting nets, the king decreed, found in the texts depict life in palaces and the everyday life of the NSM society, either in the past or in the present. The verbs or verbal groups that have been labelled as relational processes can be found in the texts, such as the verbs have, by the name, is/are, become and named. Whereas the Mental processes that have been labelled are: think, decide, know, embarrass, predicted, aware, heard.

On the whole, the participants in the "BBBB" folktale are dominated by the actor, senser and carrier participants. Whereas those participants that are directed at are dominated by the goal, range and phenomenon participants. The majority of the participants found in the "BBBB" folktale are human participants, non-factual participants and non-human participants. The participants found in the "PK" folktale are comprised of human and nonhuman participants. The $\mathrm{d}$ ominant participants in the "PK" folktale are the goal participants, that is 49 participants, equivalent to 23.79 percent. 
The circumstances found in NSM folktales are circumstance: location:time; circumstance: location: place; and circumstance: participant. The circumstance: location: time dominates NSM folktales, for example time indicators such as: one day, on time, once, every night, tomorrow night, after a long while, after cooking, the next day, at one time, one night, and every full moon.

Situation represents the situational field related to the values attached to human relationships. Situationally, text depicts institutionalized social activities, and the content discussed is at the continuum $(+)$ of specialization; tenors in situation portray participants involved in the interaction being on two continuums (+) formal and (-) formal. The status between two tenors is in an unbalanced position, the relationship between the tenors is on the $(+)$ affection, contact between tenors (-) often; the mode in a situation portrays the interaction being on planned $(+)$, the distance between the tenors is on a continuum continuum with the characteristic $(+)$ distance in place/ time, the level of text or language with the activity carried out is the language as action, reflection and reconstruction, medium continuum that is oral and written. Culture determines similar generic structure, is staged and achieves its social goals.

The legacy of values are shared, followed and practiced for centuries until it represents the identity of NSM life. In other words, NSM identity is a social construct developed by the power of semiotic language, situation, culture as its agent of realization. On the whole, semiotic power becomes the pillar of intra-ethnic and between ethnics that gel together all aspects and dimensions of NSM life that is the representation of identity potential in the dimension of human relationship.

\section{NOTES}

1. The publication of Bunga Rampai Cerita Rakyat series A (2009) comprising folktales of North Sumatra is another work by the writer and his family towards the preservation of North Sumatran oral literature heritage.

2. A number of these North Sumatran folktales are found in the analysis by Rosmawati et al. (1990) on (The structure of Serdang Malay oral literature) and the analysis by Jayawati et al. (1997) on Analisis Struktur dan Nilai Budaya Cerita Rakyat Sastra Melayu Sumtera Utara (Structure and Cultural Values of North Sumatran Malay Folktales). Jakarta: Language Centre P\&K. 


\section{REFERENCES}

Abdul Razak Karim, 1998. “Warkah-warkah Melayu Lama sebagai Genre”. Ph.D Thesis. University of Malaya, Kuala Lumpur.

Anderson, John, 1971. Mission to the East Coast of Sumatra in 1823. Singapura: Oxford University Press Halliday 1978.

Bronner, Simon J. (ed.), 2007. The Meaning of Folklore: The Analytical Essays of Alan Dundes. Logan, Utah: Utah State University Press.

Eggins, Suzanne, 2004. An Introduction to Systemic Functional Linguistics. 2nd ed. Continuum International Publishing Group Ltd.

Halliday, M.A.K., 2004. An Introduction to Functional Grammar. London: Edward Arnold.

Halliday, M.A.K., 1978. Language as Social Semiotic: The Social Interpretation of Language and Meaning. London: Edward Arnold.

Halliday, M.A.K., Matthiessen C.M.I.M., 2004. An Introduction to Functional Grammar, 3rd ed. London: Edward Arnold.

Maini Trisna Jayawati, Suslistiati, and Yeni Mulyani Supriatin, 1997. Analisis Struktur dan Nilai Budaya Cerita Rakyat Sumatera Utara Sastera Melayu. Jakarta: Pusat Pembinaan dan Pengembangan Bahasa Departemen Pendidikan dan Kebudayaan.

Martin, J.R., 1992. English Text: System and Structure. Philadelphia/Amsterdam: John Benjamins Publishing Company.

Martin, J.R., 1985. English Text: System and Structure. Philadelphia/Amsterdam: John Benjamins Publishing Company.

Santoso, Riyadi, 2003. Semiotika Sosial Pandangan terhadap Bahasa. Surabaya: Pustaka Eureka dan JP Press.

Jonathan, Sarwono, 2006. Metode Penelitian Kuantitatif dan Kualitatif. Yogyakarta: Graha Ilmu.

Rosmawati R., Anni Krisna Siregar, Ahmad Samin Siregar and Zainal Abidin, 1990. Struktur Sastera Lisan Melayu Serdang. Jakarta: Pusat Pembinaan Dan Pengembangan Bahasa.

Sinar, Tengku Luckman, 2009. Bunga Rampai Cerita Rakyat Seri A. Medan: Medan:Yayasan Kesultanan Serdang.

Sinar, Tengku Silvana, 2003. Teori \& Analisis Wacana. Pendekatan SistemikFungsional. Medan: Pustaka Bangsa Press. 


\section{GENERIC STRUCTURE OF NSM FOLKTALES}

Table 1: Generic Structure of NSM Folktales, "Batu Belah Batu Betangkup"

\begin{tabular}{|c|c|}
\hline Genre & $\begin{array}{l}\text { Generic } \\
\text { Structure }\end{array}$ \\
\hline Narrative (legend) & Element (E) \\
\hline $\begin{array}{l}\text { Dahulu kala ada sepasang suami istri yang kehidupan mereka sangat sederhana } \\
\text { Once upon a time there lived a couple who led a simple life. }\end{array}$ & [Abstract \\
\hline $\begin{array}{l}\text { Mereka tinggal di sebuah dusun yang terpencil. } \\
\text { They lived on a remote farm }\end{array}$ & [Orientation] \\
\hline $\begin{array}{l}\text { Suaminya bernama pak Abu, Kerjanya mencari rotan. } \\
\text { Istrinya bername mak Siti, Bekerja menganyam tikar. } \\
\text { The husband was called Pak Abu, he collected rattan for a living. His wife was } \\
\text { called Mak Siti and she worked by weaving mats }\end{array}$ & [Orientation] \\
\hline $\begin{array}{l}\text { Mereka belum mempunyai keturunan padahal diingininya. } \\
\text { They were childless and and longed to have a child }\end{array}$ & [Orientation] \\
\hline $\begin{array}{l}\text { Pada suatu hari sang istri bermimpi berjumpa nenek-nenek } \\
\text { One day the wife dreamt she met an old woman }\end{array}$ & $\begin{array}{l}\text { [Orientation] } \\
\text { [Complication] }\end{array}$ \\
\hline $\begin{array}{l}\text { "Oh, siapakah nenek?", kata mak Siti } \\
\text { "Aku seorang pengembara dan aku tahu apa yangMak Siti susahkan", kata } \\
\text { nenek. } \\
\text { "Oh, who are you old woman?", asked Mak Siti } \\
\text { "I am a wanderer and I know what is troubling you", said the old woman }\end{array}$ & [Complication] \\
\hline $\begin{array}{l}\text { "Jangan kuatir sebentar lagi engkau akan mempunyai anak", dan tiba-tiba } \\
\text { nenek itu menghilang. } \\
\text { "Don't worry. Soon you will have a child" and suddenly the old woman } \\
\text { disappeared. }\end{array}$ & [Complication] \\
\hline $\begin{array}{l}\text { Beberapa waktu kemudian badan mak Siti membesar hamil. } \\
\text { Not long after that, Mak Siti grew big with child }\end{array}$ & $\begin{array}{l}\text { E:[Major } \\
\text { Complication] }\end{array}$ \\
\hline $\begin{array}{l}\text { Pada waktunya, lahir seorang putri yang sangat cantikdan diberi nama Kamala } \\
\text { When the time came, a beautiful girl was born and given the name Kamala }\end{array}$ & [Resolution] \\
\hline $\begin{array}{l}\text { Sangking sayangnya pada putrinya, segala apa yang diminta putrinya selalu } \\
\text { diberikan. } \\
\text { Kamala tidak pernah membantu orang tuanya } \\
\text { Because of their great love for their daughter, they gave her everything she } \\
\text { wanted. Kamala never helped her parents }\end{array}$ & $\begin{array}{l}\text { [Complication] } \\
\text { E: [Minor } \\
\text { Complication] }\end{array}$ \\
\hline $\begin{array}{l}\text { Suatu ketika suami mak Siti meninggal dunia } \\
\text { One day mak Siti’s husband died }\end{array}$ & $\begin{array}{l}\text { E:[Major } \\
\text { Complication] }\end{array}$ \\
\hline $\begin{array}{l}\text { Mak Siti sedih dan bekerja keras sendiri. Kamala tidak mau membantu ibunya } \\
\text { Mak Siti was very sad and had to work hard all alone. Kamala did not want to } \\
\text { help her mother }\end{array}$ & $\begin{array}{l}\text { [Evaluation] } \\
{[\text { Complication }]}\end{array}$ \\
\hline $\begin{array}{l}\text { Akibat kecapaian mak Siti jatuh sakit. "Kamala, Bantu emaklah", kata mak Siti. } \\
\text { "Bantu apa, mak, saya tak pandai bekerja", jawab Kamala } \\
\text { As a result of exhaustion Mak Siti fell ill. "Kamala, please help me", said Mak } \\
\text { Siti. "Help you to do what? I don't know how to work", replied Kamala }\end{array}$ & [Complication] \\
\hline $\begin{array}{l}\text { Hati mak Siti sedih sekali } \\
\text { Mak Siti was broken-hearted. }\end{array}$ & [Evaluation] \\
\hline
\end{tabular}




\begin{tabular}{|l|l|}
\hline Genre & $\begin{array}{l}\text { Generic } \\
\text { Structure }\end{array}$ \\
\hline Narrative (legend) & Element (E) \\
\hline $\begin{array}{l}\text { Ketika hujan turun deras sekali mak Siti beranjak pergi keluar. Dia berlari } \\
\text { kearah Batu Belah. Anaknya menyusul mak Siti. } \\
\text { When the rain came pouring down Mak Siti came out. She ran in the direction } \\
\text { of the Split Rock. Her daughter followed her }\end{array}$ & [Complication] \\
\hline $\begin{array}{l}\text { Mak Siti berdo'a di depan Batu Belah agar ia dimakan Batu itu. } \\
\text { In front of the Split Rock Mak Siti prayed for the rock to swallow her up }\end{array}$ & [Complication] \\
\hline $\begin{array}{l}\text { Batu belah terbelah. } \\
\text { The rock split and opened up. }\end{array}$ & [Complication] \\
\hline $\begin{array}{l}\text { Dan mak Siti masuk ke dalam ditelan batu. } \\
\text { Mak Siti went into the rock as it swallowed her up. }\end{array}$ & [Resolution] \\
\hline $\begin{array}{l}\text { Anaknya menyadari kesalahannya. Dan menangis menyesali dirinya. } \\
\text { The daughter realized her mistake. And she cried regretting what she had done }\end{array}$ & [Evaluation] \\
\hline
\end{tabular}

Table 2 :Generic Strucure of Folktale Sri Putih Cermin” (SPC)

\begin{tabular}{|l|l|}
\hline \multicolumn{1}{|c|}{ Genre } & \multicolumn{1}{|c|}{$\begin{array}{c}\text { Generic } \\
\text { Structure }\end{array}$} \\
\hline \multicolumn{1}{|c|}{ Narrative (legend) } & Element (E) \\
\hline $\begin{array}{l}\text { Alkisah adelah seorang raja Berhale di daerah Serdang bername Tuanku Indra } \\
\text { Bestari. Raje itu mempunyai seorang putri yang cantek jelite bername Sri Putih } \\
\text { Cermin atau Tuanku Kemale Putri. Kekaseh sang putri itu bername Marajaye, } \\
\text { seorang pemude yang tampan dan gagah perkase, putra seorang panglime kerajaan. } \\
\text { This is a story about a Berhale King in Serdang whose name was Tuanku Indera } \\
\text { Bestari. The king had a beautiful daughter by the name of Sri Putih Cermin or Tuanku } \\
\text { Kemale Putri. The princess had a lover by the name of Marajaye, a handsome and } \\
\text { brave young man, the son of the kingdom's admiral }\end{array}$ & \\
\hline $\begin{array}{l}\text { Suatu ketike Marajaye pergi dari kerajaan itu kerana kawan-kawannya sengaja } \\
\text { hendak menyesatkan pemuda yang menjadi saingannye. } \\
\text { There came a time when Marajaye left the kingdom because his friends who } \\
\text { were his rivals deliberately led him astray. }\end{array}$ & $\begin{array}{l}\text { [Orientation], } \\
\text { [Complication: } \\
\text { Important } \\
\text { change] }\end{array}$ \\
\hline $\begin{array}{l}\text { Sang putri sangat sedeh memikirkan kepergian Marajaye, dan suatu malam } \\
\text { ie bermimpi burok tentang kekasihnye itu. Gadis itu memutuskan untok pergi } \\
\text { mencari kekasehnye dengan membawe tombak Serampang Sakti milik kerajaan. } \\
\text { The princess was very unhappy at Marajaye's departure and one night she had a } \\
\text { bad dream about her lover. So she decided to look for him, bringing with her the } \\
\text { spear Serampang Sakti which belonged to the kingdom. }\end{array}$ & $\begin{array}{l}\text { [Complication] } \\
\text { E: [Minor }\end{array}$ \\
$\begin{array}{l}\text { Complication] } \\
\text { Eetelah mengetahui hal ini, raje sangat sedih dan gusar. } \\
\text { When the king learnt about it, he was very sad and anxious. }\end{array}$ \\
\hline
\end{tabular}


T. THYRHAYA ZEIN

\begin{tabular}{|c|c|}
\hline Genre & $\begin{array}{c}\text { Generic } \\
\text { Structure }\end{array}$ \\
\hline Narrative (legend) & Element (E) \\
\hline $\begin{array}{l}\text { Raja tidak mengumumkan berite kepergian putrinye itu kerana merupekan aib } \\
\text { besar bagi keluarge. Beliau terpakse merahasiekan kepergian putrinye kerana } \\
\text { menurut adat resam mase tu kepergian care demikian amatlah memalukan } \\
\text { keluarge kerajaan, apelagi tombak Serampang Sakti turut pula hilang. } \\
\text { The king did not announce his princess' departure because it would greatly } \\
\text { embarrass the family. He had to keep it a secret because according to the } \\
\text { customs at that time such a departure was a big embarrassment to the royal } \\
\text { family, especially the fact that the spear Serampang Sakti was also gone. }\end{array}$ & $\begin{array}{l}\text { [Resolution] } \\
\text { E: [Major } \\
\text { Resolution] }\end{array}$ \\
\hline $\begin{array}{l}\text { Keadaan ini dimanfaatkan oleh Raja Indra Bongsu, adek raja Indra Bestari kerana } \\
\text { ia hendak merebut kerajaan. } \\
\text { This situation was taken advantage of by Raja Indra Bongsu, as he wanted to } \\
\text { seize the kingdom }\end{array}$ & [Complication] \\
\hline $\begin{array}{l}\text { Serangan pertame gagal kerana Marajaye tibe-tibe datang menyelamatkan } \\
\text { Raja Indra Bestari. Semue pengikot Indra Bongsu dapat dikalahkan dan ia lari } \\
\text { menyelamatkan dirinye. } \\
\text { The first attack failed because Marajaye suddenly came to rescue Raja Indra } \\
\text { Bestari. All Indra Bongsu's supporters were defeated and he fled to save himself }\end{array}$ & $\begin{array}{l}\text { [Resolution] } \\
\text { E: [Major } \\
\text { Resolution] }\end{array}$ \\
\hline $\begin{array}{l}\text { Indra Bongsu mengancam akan menyerang balek dan membawe Lidah Tanah } \\
\text { sebagai imbalan Marajaye. Raje Indra Bestari mengatakan bahwe Lidah Tanah } \\
\text { itu besar dan ganas. Kakinye empat dan larinya amat kencang. } \\
\text { Tiada ade yang ditakutinya kecuali tombak Serampang Sakti yang hilang } \\
\text { dibawe Kemale Putri. Marajaye terpakse pergi mencari putri Cermin kerana } \\
\text { hanya tombak Serampang Saktilah yang dapat menaklukkan si Lidah Tanah. } \\
\text { Indra Bongsu threatened to counter attack and bring Lidah Tanah to challenge } \\
\text { Marajaye. Raja Indra Bestari said that Lidah Tanah was huge and fierce. It } \\
\text { had four legs and ran like the wind. It did not fear anything except the spear } \\
\text { Serampang Sakti that had been carried away by Kemala Putri. Marajaye had to } \\
\text { look for putri Cermin because only the spear Serampang Sakti could overcome } \\
\text { Lidah Tanah }\end{array}$ & $\begin{array}{l}\text { [Complication] } \\
\text { E: [Major } \\
\text { Complication] } \\
\text { E: [Minor } \\
\text { Complication] }\end{array}$ \\
\hline $\begin{array}{l}\text { Di perjalanan, Marajaye berjumpe dengan seorang putri jelmaan kahyangan } \\
\text { bername Merak Kayangan. Disangkenye wanita itu kekasehnya, Kemala Putri } \\
\text { atau Sri Putih Cermin. Lalu menikahlah mereka. } \\
\text { On his journey, Marajaye met a mythical princess by the name of Merak } \\
\text { Kayangan. He thought it was his lover Kemala Putri or Sri Putih Cermin. And } \\
\text { so they got married. }\end{array}$ & [Resolution] \\
\hline
\end{tabular}




\begin{tabular}{|c|c|}
\hline Genre & $\begin{array}{l}\text { Generic } \\
\text { Structure }\end{array}$ \\
\hline Narrative (legend) & Element (E) \\
\hline $\begin{array}{l}\text { Tetapi Marajaye sedar bahwa wanita itu bukanlah kekasehnya lalu iapun minte } \\
\text { diri untok pulang sebentar ke bumi. } \\
\text { Sementare itu pulalah Lidah Tanah mulai bergerak menuju Kota Pare. } \\
\text { Semua yang ade di tengah jalan hancur dibuatnye. Pasukan burung yang } \\
\text { menghalanginya kering menjadi tumpukan burung sebab habis dihisap } \\
\text { darahnye. } \\
\text { But Marajaye realized she was not his lover so he asked to leave for a while and } \\
\text { he returned to earth. } \\
\text { Meanwhile Lidah Tanah started moving to Kota Pare. Everything in its path was } \\
\text { destroyed. The fleet of birds that tried to stop it dried up and became spots of } \\
\text { birds because their blood had been sucked dry. }\end{array}$ & $\begin{array}{l}\text { [Complication] } \\
\text { E: [Major } \\
\text { Complication] } \\
\text { E: [Major } \\
\text { Complication] }\end{array}$ \\
\hline $\begin{array}{l}\text { Sri Putih Cermin balek ke kerajaan dan berhasil membunuh si Lidah Tanah } \\
\text { dengan tombak Serampang Sakti. } \\
\text { Akhirnya Marajaye melangsungkan pernikahannya dengan Sri Putih Cermin. } \\
\text { Sri Putih Cermin returned to the kingdom and succeeded in killing Lidah Tanah } \\
\text { with the spear Serampang Sakti. Finally, Marajaye married Sri Putih Cermin }\end{array}$ & $\begin{array}{l}\text { [Resolution] } \\
\text { E: [Major } \\
\text { Resolution] }\end{array}$ \\
\hline $\begin{array}{l}\text { Peristiwa ini membuat Merak Kayangan gusar. } \\
\text { Ia pun menciptakan angin topan dan banjir di kerajaan itu. } \\
\text { Marajaye yang belum lama dinobatkan menjadi raje telah hilang, dan istrinya } \\
\text { bersedih menantikan kehadiran suaminya. } \\
\text { This turn of events made Merak Kayangan upset. She then unleashed stormy } \\
\text { winds and floods onto the kingdom. } \\
\text { Marajaye who had only been recently enthroned vanished and his wife became } \\
\text { despondent as she waited for him to reappear. }\end{array}$ & $\begin{array}{l}\text { [Complication] } \\
\text { E: [Minor } \\
\text { Complication] } \\
\text { E: [Major } \\
\text { Complication] }\end{array}$ \\
\hline $\begin{array}{l}\text { Kerajaan tenggelam } \\
\text { The kingdom was submerged }\end{array}$ & [Resolution] \\
\hline $\begin{array}{l}\text { dan setiap malam purname di pantai itu terdengar ratap tangis seorang wanita } \\
\text { and every night of the full moon at the beach can be heard the cries of a woman }\end{array}$ & [Evaluation] \\
\hline $\begin{array}{l}\text { sehingga pantai itu diberi name Pantai Cermin. } \\
\text { Until the beach itself became known as Pantai Cermin (Mirror Beach) }\end{array}$ & [Code] \\
\hline
\end{tabular}

Table 3: Generic Structure of Folktale Putri Kuau

\begin{tabular}{|c|c|}
\hline Genre & $\begin{array}{c}\text { Generic } \\
\text { Structure }\end{array}$ \\
\hline Legend & Element (E) \\
\hline $\begin{array}{l}\text { Adelah suatu cerita Putri Kuau. Jadi pade suatu hari raje berburu ke hutan. } \\
\text { Sesampainye di hutan didengarnye suare burung kekuau ni nyaring bunyinye. Jadi } \\
\text { kate raje macam manelah supaye dapatku burung nih. Sedap sekali suarenye kurase. } \\
\text { This is a story called Putri Kuau. One day the king went hunting in the forest. } \\
\text { When he arrived in the forest he heard the shrill sound of the Kekuau bird. So } \\
\text { the king said, how can I get that bird. I feel its such a lovely sound . }\end{array}$ & $\begin{array}{l}\text { [Oriention, } \\
\text { Abstract] }\end{array}$ \\
\hline
\end{tabular}


T. THYRHAYA ZEIN

\begin{tabular}{|c|c|}
\hline Genre & $\begin{array}{c}\text { Generic } \\
\text { Structure }\end{array}$ \\
\hline Legend & Element (E) \\
\hline $\begin{array}{l}\text { Timbullah pikiran raje untuk menjerat burung ni dengan care raje berdiri tegak } \\
\text { seperti sebatang pohon di hutan, dan akan hinggaplah burung Kekuau tu. } \\
\text { Demikianlah pikirannya raje. } \\
\text { An idea came to him to trap the bird by standing straight as a tree in the forest } \\
\text { and then the bird will perch on him. That was what the king thought. }\end{array}$ & $\begin{array}{l}\text { [Orientation] } \\
\text { [Complication: } \\
\text { [Major change] }\end{array}$ \\
\hline 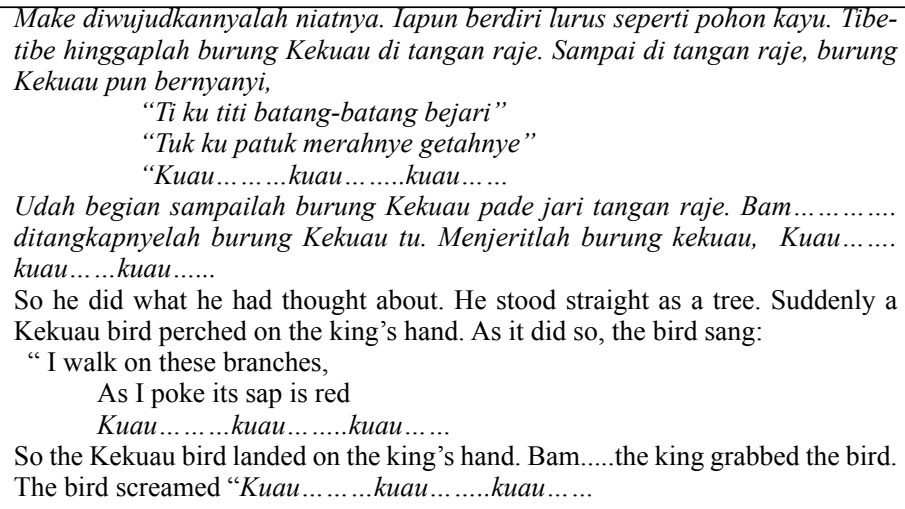 & $\begin{array}{l}\text { [Complication] } \\
\text { [Minor } \\
\text { Complication] }\end{array}$ \\
\hline $\begin{array}{l}\text { Setelah ditangkapnye make dibawelah burung tu ke istane. Sampei di istane } \\
\text { dibuatkannye sangkar untuk burung kekuau. Mendai sangkar yang dibuatnye. } \\
\text { Sesudah selesai sangkarnye, dimasukkannye burung Kekuau itu ke dalam } \\
\text { sangkarnye dan ditambatkannya sangkar burung Kekuau pade batang pohon } \\
\text { dekat sungai istane. } \\
\text { Sudahlah menjaditabiatraje kalau setiap malam hari ie menjale ikan, tetapi ikan } \\
\text { yang ie dapat selalu dimasukkannye lagi ke dalam sungai. Begianlah setiap kali } \\
\text { ia lakukan kalau menjale ikan. } \\
\text { After he caught the bird, he brought it to the palace. When they arrived at the } \\
\text { palace a cage was made for the kekuau bird. It was a beautiful cage. When the } \\
\text { cage was ready, the kuau bird was placed inside and the cage was tied to a tree } \\
\text { branch near a river by the palace. } \\
\text { It was the king's habit to catch fish every night in his net but he would throw } \\
\text { back the fish he caught into the river. This is what he would do every time he } \\
\text { went fishing. }\end{array}$ & $\begin{array}{l}\text { [Major } \\
\text { Resolution] }\end{array}$ \\
\hline $\begin{array}{l}\text { Pada suatu malam raje bemimpi. Dalam mimpinye ia didatangi orang tue dan } \\
\text { orang tua itu betanye padenye, "Hai raje nan budiman, ikan yang raje jale tiade } \\
\text { yang empunye, make bolehlah kalau raje memakannye". } \\
\text { Raje terbangun dan bukan kepalang terperanjatnye ketike orang tua tu hilang } \\
\text { entah ke mane rimbenye. } \\
\text { One night the king had a dream. In his dream an old man came to him and spoke } \\
\text { to him "Oh noble king, the fish that you catch do not belong to anyone, so you } \\
\text { can eat the fish" } \\
\text { The king got up and was shocked to see that the old man had disappeared. }\end{array}$ & $\begin{array}{l}\text { [Complication] } \\
\text { [ Minor } \\
\text { Complication] }\end{array}$ \\
\hline $\begin{array}{l}\text { Raje sadar rupenye ia hanye bemimpi. } \\
\text { Then the king realized that it was just a dream }\end{array}$ & $\begin{array}{l}\text { [Major } \\
\text { Resolution] }\end{array}$ \\
\hline
\end{tabular}




\begin{tabular}{|c|c|}
\hline Genre & $\begin{array}{c}\text { Generic } \\
\text { Structure }\end{array}$ \\
\hline Legend & Element (E) \\
\hline $\begin{array}{l}\text { Pade esok malamnye ie lalu ke sungai untuk menjale ikan sebagemane biasanye. } \\
\text { Raje senang bukan maen kerana banyak ikan didapatnye. Dikumpulkannye ikan- } \\
\text { ikan itu pade karung, dan ie tetap saje menjale. Sudah begian lame ie menjale, } \\
\text { make ie pun beranjak ndak pulang ke istane. } \\
\text { The following night he went to the river to catch fish as usual. He was happy as } \\
\text { he was able to catch a lot of fish. He gathered the fish into a sack and went on } \\
\text { catching more fish. After some time, he left for the palace }\end{array}$ & [Resolution] \\
\hline $\begin{array}{l}\text { Tapi betape terperanjatnye ie, dikelehnye ikan-ikan tu sude dimasak. Bepikirlah } \\
\text { raje, siape gerangan yang memasakkan ikan yang ie dapat? } \\
\text { Raje pun curige dan ingin tau siape sebenarnye yang memasak ikan hasil } \\
\text { tangkapannye. } \\
\text { Pade suatu malam, seperti biasenye, raje pun lalu ke sungei untukmenjale ikan. } \\
\text { Dalam pikirannye ie nak mencari tau siape gerangan yang memasak ikannye. } \\
\text { Sambilmenjale sekali-kali ie mengkeleh ikan hasiljaleannye. Ia terus menunggu. } \\
\text { Tibe-tibe dikelehnye ade puteri cantek rupawan datang mengambil ikan hasil } \\
\text { tangkapannye. Raje pun terperanjat bukan kepalang. Dari mane datangnye } \\
\text { puteri cantek tu? pikirnye. Lame ie mengeleh puteri nan cantek yang membawe } \\
\text { ikan-ikannya untuk dimasak. Ia terus mengintip puteri yang sedang memasak. } \\
\text { Setelah selesai memasak, puteri pun menuju ke arah sangkar burung Kekuau. } \\
\text { Sesampai di sangkar burung Kekuau, puteripun melangkah masuk ke dalam } \\
\text { sangkar tetapi tibe-tibe puteri tersebut lenyap. Rupenye jinnye burung Kekuau } \\
\text { itu adalah puteri nan cantek. Berfikirlah raje bagaimana carenye agar puteri } \\
\text { tidak kembali menjadi burung Kekuau. } \\
\text { But he got a shock when he saw that the fish had been cooked. The king wondered, } \\
\text { who would be cooking the fish that he caught? The king became suspicious and } \\
\text { wanted to find out who cooked the fish that he caught. } \\
\text { One night, as usual, the king went to the river to catch fish with his net. In his } \\
\text { mind he wanted to find out who cooked his fish. While casting his net he would } \\
\text { also look at the fish he caught. And he waited. } \\
\text { Suddenly he saw a beautiful princess appear and take away his catch. The king } \\
\text { was astounded. From where did this beautiful princess appear? He wondered. } \\
\text { For a long time, he stared at the princess taking away his fish to be cooked. He } \\
\text { then spied on her cooking the fish. } \\
\text { After she finished cooking, the princess walked to the cage of the Kekuau bird. } \\
\text { When she reached the cage she stepped into it and suddenly vanished. So the kuau } \\
\text { bird's genie was a beautiful princess. The king then thought of ways to prevent } \\
\text { the princess from turning back into the kekuau bird. }\end{array}$ & $\begin{array}{l}\text { [Major } \\
\text { Complication] } \\
\text { [ Minor } \\
\text { Complication] }\end{array}$ \\
\hline $\begin{array}{l}\text { Esoknya seperti biasa ie pergi ke sungai untuk menjale ikan. Setelah beberape } \\
\text { ikan ie dapat, ditambatkannye ikan tu pade tempat yang agak jauh dari sangkar } \\
\text { burung Kekuau. } \\
\text { The next day, as usual he went to the river to catch fish. After catching several, } \\
\text { he tied up the fish at a place that was quite far from the cage of the kekuau bird. }\end{array}$ & [Resolution] \\
\hline
\end{tabular}


T. THYRHAYA ZEIN

\begin{tabular}{|c|c|}
\hline Genre & $\begin{array}{c}\text { Generic } \\
\text { Structure }\end{array}$ \\
\hline Legend & Element (E) \\
\hline $\begin{array}{l}\text { Seperti biase burung Kekuaupun keluarlah dari sangkarnye dan mulailah ie } \\
\text { memasak ikan jalean raja. Pada waktu puteri burung Kekuau sedang memasak, } \\
\text { diam-diam diambel raje sangkar burung Kekuau dan dibunikannye sarang itu. } \\
\text { As usual, the Kekuau bird came out from the cage and began to cook the fish } \\
\text { caught by the king. At the time the kekuau bird princess was cooking, the king } \\
\text { quietly removed the cage and hid it }\end{array}$ & $\begin{array}{l}\text { [Minor } \\
\text { Complication] }\end{array}$ \\
\hline $\begin{array}{l}\text { Dari jauh diamatinye puteri yang lagi memasak. Selesai masak seperti biasanye } \\
\text { puteri burung Kekuau berniat nak kembali ke sangkarnye. Tapi sudah dicari- } \\
\text { carinye sangkarnye tiadejuge nampak. Hatinya mulai gundah. Dimane pikirnye } \\
\text { sangkarnye. Lame puteri Kekuau mencari-cari sangkarnye tape tiade juga } \\
\text { dapat. Dari jauh dikelehnye raje sedang menjale ikan. Didatanginyelah raje, } \\
\text { lalu ia bertanya, } \\
\text { "Harap diampun tuanku, sangkar patik ade tuanku simpan?", } \\
\text { "Tiade", jawabnye. } \\
\text { "Maye pule tiade, tuanku lah yang menyimpan. Tiada siape pun yang ade di } \\
\text { sini", kate puteri Kekuau. } \\
\text { Lame-lame, kecekpunya kecek diceritakannyelah, bahwa rajelahyang menyimpan } \\
\text { sangkarnye. } \\
\text { "Tapi beginin, tide ku bagi engkau masuk lagi ke sangkar tu", kate raje. } \\
\text { "Jangan begianlah, tuanku", jawab putri kuau. "Hambe ndak masuk ke dalam } \\
\text { sangkar hambe", tuanku. } \\
\text { "Tide!" jawab Tuanku } \\
\text { From far he could see the princess still cooking. As usual, after cooking the } \\
\text { princess wanted to return to her cage. But when she looked for it she could not } \\
\text { find it. She began to be worried. Where is the cage she wondered. She looked for } \\
\text { it for a long time but still could not find it. From far she could see the king still } \\
\text { casting his net. She approached him and asked "Forgive me your highness, is } \\
\text { my cage in your keeping?" "No", he said. "How can that be, your highness, you } \\
\text { must be keeping my cage. There is no one else here", said the Kekuau Princess. } \\
\text { Finally after a lot of coaxing, he admitted that he was keeping the cage. } \\
\text { "Its like this. I will not allow you to enter the cage again", said the king. } \\
\text { "Please don't do that your highness. I want to go back into my cage", replied } \\
\text { the princess } \\
\text { "No" said the king }\end{array}$ & $\begin{array}{l}\text { [Major } \\
\text { Complication] }\end{array}$ \\
\hline $\begin{array}{l}\text { Lame-lame diambil kata sepakat bahwe raje ingin puteri Kekuau tinggal } \\
\text { bersamanye. Akhirnya kawinlah raje dengan puteri burung kekuau. } \\
\text { Finally they came to an agreement. The king wanted the Kekuau princess to live } \\
\text { with him. In the end the king married the princess, }\end{array}$ & $\begin{array}{l}\text { [Major } \\
\text { Resolution] }\end{array}$ \\
\hline $\begin{array}{l}\text { Tapi dalam perkawinan itu ade satu syarat yang diminte oleh puteri. Syarat itu } \\
\text { adelah "Kalaulah sudah anak kita laher, walau pun laki-laki ataupun perempuan, } \\
\text { jangan suruh hambe menyanyi, kalau tuanku suroh ambe menyanyi maka bepisahlah } \\
\text { kite", kate puteri burung Kekuau. } \\
\text { Raje terperanjat dan tidak pecaye apa yang dikatekan puteri tapi Raje menurut } \\
\text { saje dan menyetujui persyaratan itu. } \\
\text { But the princess insisted on one condition. The condition was : "if I deliver a } \\
\text { child, no matter whether its a girl or boy, do not ask me to sing, if you ask me to } \\
\text { sing we will be separated" } \\
\text { The king was surprised and did not believe what the princess said. But he acquiesced } \\
\text { and agreed to the condition. }\end{array}$ & $\begin{array}{l}\text { [Minor } \\
\text { Complication] }\end{array}$ \\
\hline
\end{tabular}




\begin{tabular}{|c|c|}
\hline Genre & $\begin{array}{c}\text { Generic } \\
\text { Structure }\end{array}$ \\
\hline Legend & Element (E) \\
\hline $\begin{array}{l}\text { Pendek cerite lamelah raje dan burung puteri Kekuau menjalani bahtera rumah } \\
\text { tangga dan dapatlah mereka satu anak laki-laki. Pada satu mase rupenye raje } \\
\text { ade keinginannye. Keinginannye itu ielah menyuroh pemaisurinye memasak } \\
\text { seekor burung sebab Raje tahu puteri burung Kekuau pandai memasak. Raje } \\
\text { menyuroh permaisurinya memasak seekor burung dengan empat puluh empat } \\
\text { macam masakan. Lalu permaisuripun memasakkan burung itu dengan empat } \\
\text { puluh empat macam masakan. } \\
\text { To cut the story short, the king and the Kekuau bird Princess settled down and } \\
\text { they were blessed with a son. Then the king had a strong desire for a bird dish. } \\
\text { So he asked his queen to cook a bird because he knew that the Princess Kekuau } \\
\text { can cook well. He asked her to cook the bird in } 44 \text { types of dishes. So the queen } \\
\text { cooked the bird in } 44 \text { types of dishes }\end{array}$ & [Resolution] \\
\hline $\begin{array}{l}\text { Sudah siap memasak hati raje belum juge puas. Inginjuge rasenye ie mendengarkan } \\
\text { nyanyian puteri. } \\
\text { "Oh tuan puteri menyanyilah engkau, radukan anak kita nin, kate raje. } \\
\text { After she finished cooking the king was still not satisfied. He had this desire to hear } \\
\text { her sing. "Oh princess, why don't you sing, a lullaby for our son", said the king }\end{array}$ & $\begin{array}{l}{[\text { Minor }} \\
\text { Complication] }\end{array}$ \\
\hline $\begin{array}{l}\text { Tuan puteri pun mengayun anakndenye tapi tak ndak menyanyi. Memang } \\
\text { anakndenye diayunnye setiap hari sampai besar tapi tide pernah diradukannye. } \\
\text { Ia hanye mengayunkannye saje. } \\
\text { The princess cradled her son in her arms but did not sing. Everyday she had been } \\
\text { cradling her son to sleep but she had never sung. She just cradled her son in her arms. }\end{array}$ & $\begin{array}{l}\text { [Major } \\
\text { Resolution] }\end{array}$ \\
\hline $\begin{array}{l}\text { Suatu hari ditanyenye lagi tuan puteri. } \\
\text { "Tuan puteri ngapelah tuan puteri tak ndak menyanyi". } \\
\text { "Ambe ade pantang, Tuanku, jawab tuan puteri. Ambe tide berani menyanyi". } \\
\text { Jinye puteri. } \\
\text { "Yah .... Ngape, tuan puteri?", } \\
\text { "Pantang", Tuanku. } \\
\text { One day he asked her again "Princess, why don't you sing?". "I can't. Its taboo } \\
\text { your highness", the princess replied. I dare not sing". } \\
\text { "Why princess?" } \\
\text { "Taboo" }\end{array}$ & $\begin{array}{l}\text { [Minor } \\
\text { Complication] }\end{array}$ \\
\hline 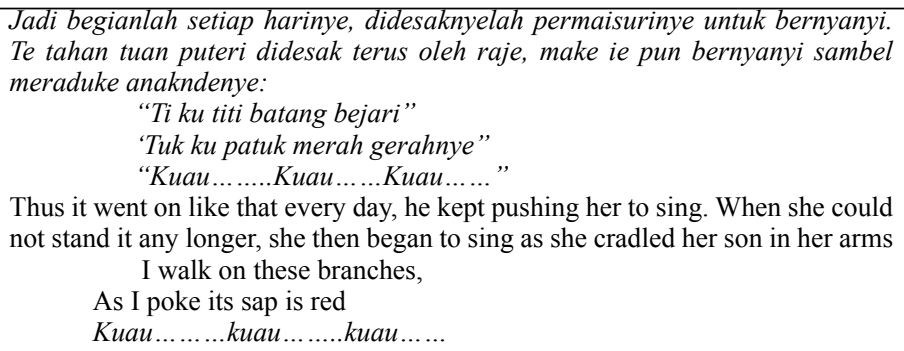 & $\begin{array}{l}\text { [Minor } \\
\text { Complication] }\end{array}$ \\
\hline $\begin{array}{l}\text { Segitu ie bernyanyi, bus......! ie pun terbang dari jendela istane dan berubah } \\
\text { jadi burung Kekuau. } \\
\text { As she sang, bus... She flew out the palace window and transformed into the } \\
\text { kekuau bird }\end{array}$ & $\begin{array}{l}\text { [Major } \\
\text { Complication] }\end{array}$ \\
\hline
\end{tabular}


T. THYRHAYA ZEIN

\begin{tabular}{|l|l|}
\hline \multicolumn{1}{|c|}{ Genre } & \multicolumn{1}{c|}{$\begin{array}{c}\text { Generic } \\
\text { Structure }\end{array}$} \\
\hline \multicolumn{1}{|c|}{ Legend } & Element (E) \\
\hline $\begin{array}{l}\text { Make ie pun hinggaplah pade batang pokok yang besar. Segian ie hinggap } \\
\text { bam.....! tumbang pokok tu. Jadi segian ie hinggap pade batang pokok, batang } \\
\text { pokok pun tumbang. } \\
\text { It then perched on a branch of a big tree. As it landed on the branch, bam...! The } \\
\text { tree fell. Any tree branch that it perched on, the tree would fall }\end{array}$ & $\begin{array}{l}\text { [Major } \\
\text { Complication] }\end{array}$ \\
\hline $\begin{array}{l}\text { Make lame-lame habislah pokokyangade di istane. Istane pun hancur ketimpekayu. } \\
\text { Akhirnye matilah raje besame anaknye. } \\
\text { Finally all the trees at the palace were gone. The palace too was destroyed, crushed } \\
\text { by wood. In the end, the king died with his son. }\end{array}$ & [Resolution] \\
\hline
\end{tabular}

(Translated by Shah Rezad Ibrahim) 